\title{
Development of Pancytopenia After Single Low-Dose Methotrexate Therapy in Patients with Chronic Kidney Disease: a Review of the Literature
}

Ibrahim Akdag 1 , (D) Alparslan Ersoy ${ }^{2}$ (D)

${ }^{1}$ Division of Nephrology, Diskapi Yildirim Beyazit Training and Research Hospital, Ankara, Turkey

${ }^{2}$ Division of Nephrology, Department of Internal Medicine, Uludag University Faculty of Medicine, Bursa, Turkey

\begin{abstract}
Methotrexate (MTX) is widely used in the treatment of both rheumatoid arthritis (RA) and psoriatic arthritis (PA) with a side effect of pancytopenia. However, very few cases of severe pancytopenia caused by low-dose MTX therapy have been described in chronic kidney disease. Pancytopenia occurred after using a single dose of MTX in our three patients with chronic kidney dysfunction. While one patient died due to sepsis and multiple organ failure, the others recovered. The severity of MTXinduced pancytopenia in our cases was likely related to the underlying kidney disease. These cases suggest that uremic patients may develop severe fatal bone marrow toxicity even with a single dose of MTX. Therefore, complete blood count monitoring after MTX treatment in this population would be beneficial.
\end{abstract}

Turk J Int Med 2020;2(3):83-90 DOI: $10.46310 /$ tjim.766086

Keywords: Chronic kidney disease, methotrexate, psoriatic arthritis, rheumatoid arthritis, pancytopenia

\section{Introduction}

Methotrexate (MTX), a classical antifolate, has gained wide acceptance due to its efficacy in a variety of inflammatory rheumatological disorders, including rheumathoid arthritis (RA) and psoriatic arthritis (PA)., ${ }^{1,2}$ Although MTX at doses as low as $5-25 \mathrm{mg}$ per week is the firstline therapy for RA, inter- and intra-patient variability in the response to treatment with the contribution of variability in concentrations of active polyglutamate metabolites can affect clinical efficacy and toxicity. ${ }^{3}$ The absence of neutropenia or agranulocytosis episodes with MTX treatment at a dose of $7.5 \mathrm{mg}$ per week for two years in patients with RA over 65 years of age indicates that this treatment is safe even in the elderly. ${ }^{4}$ However, rare adverse hematological side effects associated with low-dose MTX, including fatal pancytopenia, are an increased cause of concern in patients with rheumatological disorders and renal dysfunction. ${ }^{3,5}$ Herein, three patients with chronic kidney disease (CKD) who developed pancytopenia after a single oral or intramuscular dose of MTX are presented.

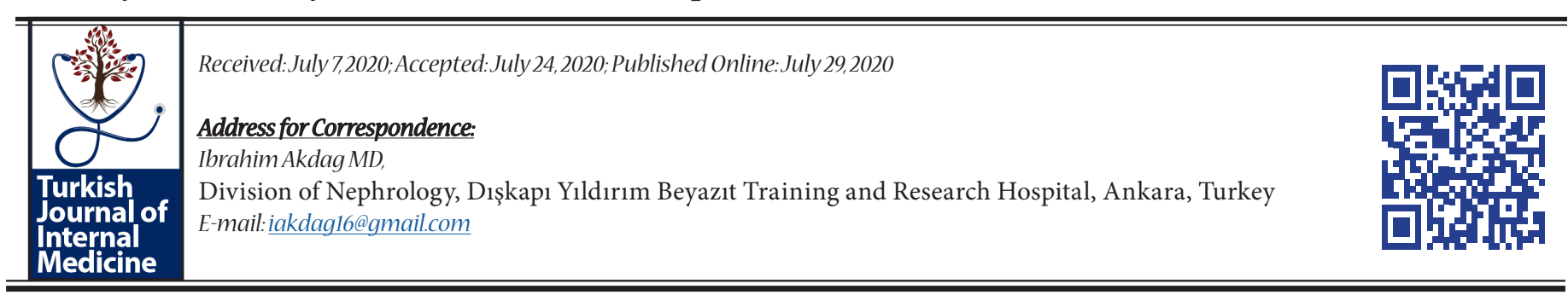




\section{Case Report}

Case 1. The first case was a 58-year-old woman with a history of chronic hypertension and kidney dysfunction. She had RA for 30 years. Serum creatinine level was $1.4 \mathrm{mg} / \mathrm{dL}$ and creatinine clearance was $43 \mathrm{~mL} / \mathrm{min}$. MTX was prescribed because of insufficient effect of steroids on increased joint pain, and a single dose of $12.5 \mathrm{mg}$ was administered orally. Abdominal pain, chest discomfort, vomiting, and skin rush developed 5 days after administration of single-dose MTX. Petechial lesions on her pretibial area and ecchymosis on anterior aspect of left knee were remarkable. Laboratory findings at admission included severe pancytopenia: white blood cells 1,200 cells $/ \mu \mathrm{L}$ with 160 cells $/ \mu \mathrm{L}$ neutrophils, platelets 8,800 cells $/ \mu \mathrm{L}$ and hemoglobin $9.1 \mathrm{~g} /$ $\mathrm{dL}$. A bone marrow aspiration revealed erythroid hyperplasia with megaloblastic maturation and relative preponderance of eosinophils in the granulocytic series without atypical or blastic cells, as well as marked suppression of the megakaryocytic series. The patient was diagnosed as having MTX-induced pancytopenia and myelosuppression. She was treated with folinic acid and granulocyte colony stimulating factor. Two units of red blood cells and two units of platelets were replaced. On the 13th day of her hospitalization, she recovered completely and was discharged.

Case 2. The second case was a 43-year-old male patient with psoriasis and PA for 20 years. He had been on hemodialysis treatment for 3 months due to end-stage renal disease. MTX was prescribed because of a diffuse psoriatic eruption, and a single dose of $12.5 \mathrm{mg}$ was administered orally. 7 days after the use of MTX, the patient applied with complaints of diarrhea, anorexia, chills, fever and not feeling well for two days. In his physical examination, blood pressure was $100 / 60 \mathrm{mmHg}$, pulse rate was 110 beats/min, body temperature was $38.5^{\circ} \mathrm{C}$, and respiratory rate was $20 / \mathrm{min}$. Laboratory findings at the admission showed pancytopenia with a hemoglobin level of $5.9 \mathrm{~g} /$ $\mathrm{dL}$, a white blood cell count of 3,100 cells $/ \mu \mathrm{L}$ with 590 cells $/ \mu \mathrm{L}$ neutrophils, and a platelet count of 31,300 cells $/ \mu \mathrm{L}$. The patient was diagnosed as having MTX-induced pancytopenia and neutropenicsepsis. He was treated with amikacin, cephapirin, folinic acid and granulocyte colony stimulating factor. After two days, his white blood cell dropped to 400 cells $/ \mu \mathrm{L}$ without neutrophils. Then, the patient's need for inotropic agent and blood product transfusion continued. Eventually, the patient died with multiple organ failure due to sepsis.

Case 3. The third case was a 22-year-old woman patient with psoriasis for 20 years. She had been on hemodialysis treatment for 13 years due to end-stage renal disease. A dermotologist started a single dose of $10 \mathrm{mg}$ intramuscular MTX therapy per week for active psoriatic lesions. Five days later, she admitted to the emergency room of our center with complaints of fever, vomiting, nausea, diarrhea, epistaxis and stomatitis. In her physical examination, blood pressure was 100/60 $\mathrm{mmHg}$, pulse rate was 107 beats/min, body temperature was $39.5^{\circ} \mathrm{C}$, and she had multiple oral mucosites. Laboratory analysis revealed the following: pancytopenia, with a hemoglobin level of $5.5 \mathrm{~g} / \mathrm{dL}$, a white blood cell count of 1,810 cells $/ \mu \mathrm{L}$ with 390 cells $/ \mu \mathrm{L}$ neutrophils, and a platelet count of 72,000 cells $/ \mu \mathrm{L}$. The patient was diagnosed as having MTX-induced pancytopenia and neutropenic sepsis. She was treated with meropenem, fungostatin gargling, folinic acid and granulocyte colony stimulating factor. Due to the deepening of pancytopenia, 12 units of fresh frozen plasma, 10 units of platelet concentrate and two units of red blood cell support were required. On the $12^{\text {th }}$ day of treatment, the patient's blood values improved. She was discharged on the $21^{\text {st }}$ day after admission.

\section{Discussion}

Long-term weekly low-dose MTX therapy has proven to be highly effective in RA and other rheumatic diseases. Although myelosuppression is major dose-limiting side effect of high-dose MTX, low-dose MTX therapy can infrequently cause significant side effects such as hepatotoxicity, pulmonary damage and myelosuppression. ${ }^{6}$ Lowdose weekly therapy in RA can lead hematologic toxicity associated with macrocytic red blood cells due to folate depletion. ${ }^{7}$ Occasionally, anemia, leukopenia or thrombocytopenia can occur even without significant reduction in other cell lines. 6 But, the development of pancytopenia is a more 
severe complication after low-dose MTX use..$^{8-11}$

A literature search found a total of 70 cases with pancytopenia related to low-dose MTX therapy in RA patients between 1980 to 1995 years. ${ }^{12}$ In most patients, the mean weekly MTX dose was 7.5-10 mg and the mean cumulative dose was 675 mg (range: 10-4,800). 12 (17.1\%) patients died, 10 of 12 patients had renal dysfunction and 9 had concomitant infection. The toxicity data from longterm prospective studies involving 511 patients treated with MTX for at least 13 weeks found an estimated incidence of pancytopenia of $1.4 \%$ $(n=7) .{ }^{12}$ In a prospective follow-up study assessed the frequency of MTX-induced pancytopenia in 157 patients with psoriasis, an overall incidence of pancytopenia was $11 \% .^{2}$ In other study, the rate of pancytopenia was lower in 284 RA patients who received weekly oral low-dose MTX therapy $(\mathrm{n}=4$, $1.4 \%) .^{13}$ The cumulative dose of MTX ranged from $15 \mathrm{mg}$ to $760 \mathrm{mg}$ at the time of pancytopenia. In another study, the prevalence of cytopenia was $2.38 \%(\mathrm{n}=10)$ in 420 patients with RA, and only 1 patient had pancytopenia.14 Serum creatinine values of three patients with cytopenia were higher than $1.2 \mathrm{mg} / \mathrm{dL}$. Patients with cytopenia received MTX at a weekly dose of 2.5-8 $\mathrm{mg}$ for a mean of 60 months (range: 10-119).${ }^{14}$ Intriguingly, no correlation was found between the total MTX dose and the severity of side effects. ${ }^{2}$ In case series of Sosin et al..$^{15}$, MTX doses and durations of four cases with myelosuppression were $17.5 \mathrm{mg}$ for 2 months, $5 \mathrm{mg}$ for 6 months, $5 \mathrm{mg}$ for 10 years and $10 \mathrm{mg}$ for 7 months. Similarly, one of CalvoRomero's ${ }^{16} 2$ patients who developed MTX-related pancytopenia used $15 \mathrm{mg}$ of MTX for 10 days and the other used 1,030 mg of MTX for 23 months. A total of five patients of around 2,500 patients of RA who prescribed MTX between January 1996 to September 2005 developed MTX-induced pancytopenia, and the cumulative dose of MTX of patients varied from $25 \mathrm{mg}$ to $2.1 \mathrm{~g} .{ }^{17}$ Several patients developed fatal pancytopenia even after the minimal cumulative dose of MTX as low as 10 $\mathrm{mg}$, and may occur at any time during treatment. ${ }^{12}$ In another report, the minimal single MTX dose leading to fatal neutropenia in patients with chronic uraemia had been reported to be $2.5 \mathrm{mg}$ per week..$^{18}$

After starting MTX therapy, pancytopenia may occur suddenly within 1-2 months with a possible idiosyncratic reaction or years later due to dose- dependent cumulative effect. ${ }^{19}$ Myelosuppression can be due to impaired MTX excretion and/or accumulation of its metabolites intracellularly. Numerous riskfactors for MTX-induced pancytopenia include impaired renal function, hypoalbuminemia, low folate levels, concurrent infection, advanced age, multiple drugs usage and lack of folate supplementation. ${ }^{20}$ Previous studies have shown association of cytopenia with C677T and 1298AA polymorphism. ${ }^{21,22}$

Considering the literature data, it is clear that presence of renal dysfunction is the most important risk factor of MTX toxicity including hematological effects. ${ }^{5,12,23}$ Renal impairment rates in patients with pancytopenia in different series have been reported between $30.4 \%$ and $54.3 \% .^{12,24,25}$ Approximately $35 \%$ of MTX is bound to plasma proteins. It is mainly cleared through the kidneys and is excreted $80 \%$ to $90 \%$ of the absorbed amount is excreted in the urine unchanged within 48 hours by glomerular filtration and active tubular secretion, mostly within the first 8 hours. ${ }^{1,3,5}$ Therefore, impaired renal excretion of MTX and prolonged exposure to the drug increase the risk of myelosuppression and other toxicities. If occurrence of an acute disease or addition or change of a non-steroidal anti-inflammatory drug (NSAID) impair renal function or MTX is taken daily instead of weekly, low-dose MTX is more likely to cause myelosuppression. ${ }^{6}$ High-dose MTX related-kidney damage, which can occur due to precipitation of MTX crystals and tubular damage, is very rare with chronic low-dose therapy. In a study of twenty-one RA patients receiving a standard $7.5 \mathrm{mg}$ dose of weekly MTX and concomitant NSAID therapy, no differences in area under the serum concentration versus time curve (AUC), time to maximal MTX concentration (Tmax), or maximal MTX concentration achieved post-dosing (Cmax) were observed over a 2 year period. Creatinine clearance decreased significantly after 6 months of treatment. ${ }^{26}$

When the cases with CKD published in the literature are evaluated, it is seen that after multiple doses or prolonged use of MTX, patients develop bicytopenia or pancytopenia (Table 1)., 5,23-27-38 However, similar to our cases, pancytopenia has rarely been reported after a single dose of MTX (Table 2). ${ }^{18,40-42} 16$ (7 females, 43.8\%) of 24 patients with CKD who developed bicytopenia or pancytopenia received multiple MTX doses, while 
8 (4 females, 50\%) received a single dose of MTX. Median ages [54 (range: 22-68) vs. 60 (range: 21-76) years, respectively], gender distributions and dialysis modalities between singledose and multiple-dose MTX groups were comparable. One of our patients was stage $3 \mathrm{CKD}, 17$ out of 24 patients were on maintenance hemodialysis and 6 were on peritoneal dialysis. Depletion of folate prior to the initiation of MTX and the lack of folate supplementation may have contributed to bone marrow toxicity in some patients. ${ }^{27}$ If the mean corpuscular volume (MCV) is above $94 \mathrm{fl}$ during MTX treatment, hematological toxicities may be predicted in some patients. Co-administration of MTX with low-dose oral folic acid (5 mg/ day) can sometimes reduce the incidence of myelosuppression. However, leukopenia may occur despite folic acid or folinic acid supplements in uremic patients receiving long-term low-dose MTX, and folate supplement may not reduce the risk of hematological toxicity and the possibility of discontinuation of treatment. ${ }^{28,39}$ None of those receiving a single dose of MTX received folic acid or calcium folinate supplements before treatment. Only 6 of those receiving multiple doses of MTX received pre-treatment supplement. None of our patients used folic acid before MTX.

In patients with MTX-induced pancytopenia, oral mucositis and fever are the common symptoms at presentation, similar to our cases (Tables 1 and 2). These symptoms should alert the clinician to suspect neutropenia. Non-survivor uremic patients with pancytopenia had lower nadir leukocyte counts and higher MTX levels than those of survivors. The highest methotrexate level leads to more severe bone marrow toxicity and the lowest leukocyte count and may worsen the prognosis. ${ }^{32}$ The median cumulative MTX dose in multiple-dose MTX group was statistically insignificantly higher than that of single dose MTX group [15 (range: 7.5-100) vs. 7.5 (range: 2.5-25) $\mathrm{mg}$, respectively, $\mathrm{p}=0.053$ ]. However, the cumulative dose of 3 patients was not reported. After developing MTX toxicity, 12 of 24 patients had MTX concentration measured at different times. Different toxicity reference values have been reported in the literature $(>0.1$, $>0.01$ or $>0.02 \mu \mathrm{mol} / \mathrm{L})$. In some patients, the MTX concentration was very high (range: 0.06$0.53 \mu \mathrm{mol} / \mathrm{L}) 1^{8,31-33,37,38,41}$, while in others it was measured normal $(0.005 \mu \mathrm{mol} / \mathrm{L})^{29}$ or slightly high (range: $0.02-0.03 \mu \mathrm{mol} / \mathrm{L}$ ). ${ }^{34,36,40,42}$ In our cases, MTX level could not be measured. Really, myelosuppression may become evident in the setting of prolonged elevated serum levels of MTX. Mortality rates of single dose $(n=3,37.5 \%)$ and multiple-dose $(n=4,25 \%)$ MTX groups were similar. The main cause of death in pancytopenic patients with CKD was sepsis and multiple organ failure. In analysis of 25 cases with MTX-induced pancytopenia between 1999 and 2004, the severity of pancytopenia correlated with MTX dose. 32\% $(n=8)$ of the patients had impaired renal function, and the mortality rate was $28 \%{ }^{24}$

Currently, MTX use is controversial in dialysis patients, even at a low dose. Stage 2 CKD is not associated with increased toxicity. ${ }^{43}$ A significant reduction of MTX clearance is observed in patients with stage $3 \mathrm{CKD}$. However, no prediction for the individual patient is possible due to the wide variation in pharmacokinetics. ${ }^{44}$ Peritoneal dialysis, conventional hemodialysis, hemoperfusion and plasmapheresis have been reported to have little effect on the removal of polyglutamated MTX metabolites within cells in MTX intoxication. . $18,29,45,46^{\text {Hemodialysis }}$ and hemoperfusion methods can effectively remove approximately $50 \%$ of MTX that binds to proteins. However, with a post-dialysis rebound, MTX concentration returns to $90-100 \%$ of its level prior to the procedure. ${ }^{29}$ While plasma MTX concentrations can be reduced by $26 \%$ by plasma exchange or exchange transfusion, hemodiafiltration can decrease its concentrations by $82 \%$ over 3 days. ${ }^{36}$ Diskin et al ${ }^{33}$ reported that the clearance of MTX on peritoneal dialysis was less effective than that on hemodialysis. In contrast, high flux hemodialysis reduced plasma MTX concentrations by $75.5 \%$ within $4-12$ hours. ${ }^{47}$ In another study, serum levels of MTX have been shown to be efficiently reduced by high-flux hemodialysis dialyzers of $92.1 \pm 10.3 \mathrm{~mL} / \mathrm{min}^{48}$ Intensive-cycler peritoneal dialysis and high-flux hemodialysis are potential options for effective removal of $\mathrm{MTX}^{49}$ However, the possibility of removing the drug in the case of toxicity may still be limited. ${ }^{50}$ We did not change the current dialysis treatment modalities in both of our patients. In the presence of advanced renal failure and dialysis patients, even at low doses, MTX has a higher risk of toxicity due to higher plasma levels and longer half-lives. MTX can be detected even up 


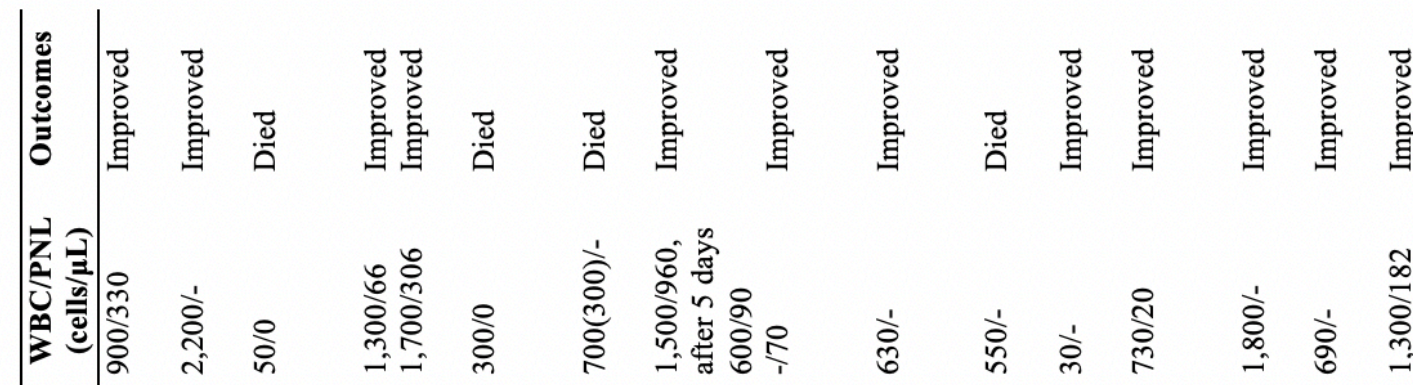

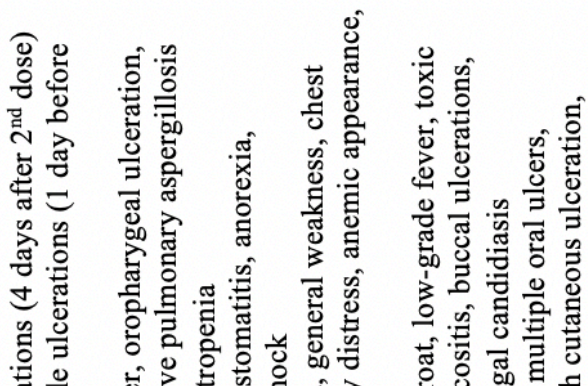

$\underset{凶}{\otimes}$

离

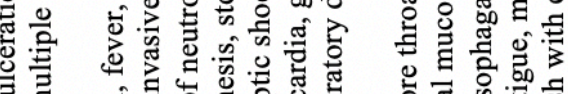

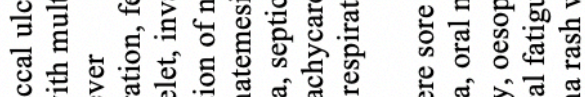

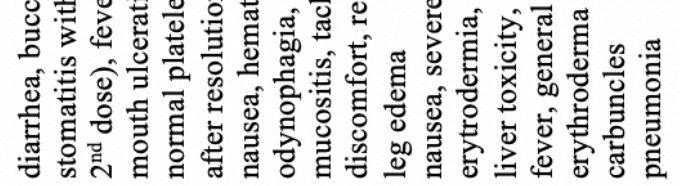

$\because 7$

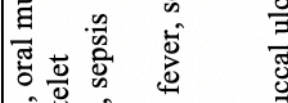

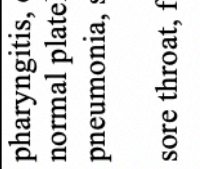

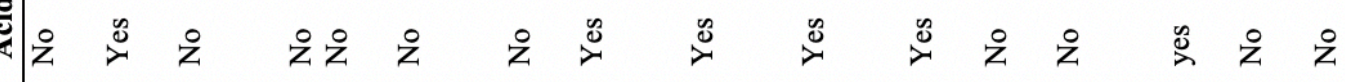

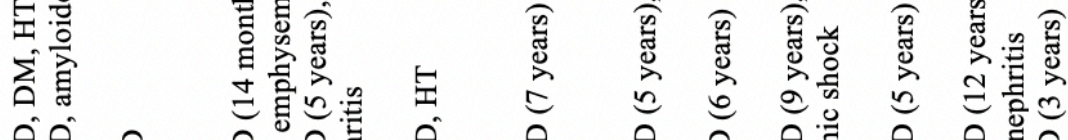


Table 2. The characteristics of patients with chronic kidney disease (CKD) who developed pancytopenia after single dose methotrexate (MTX)

\begin{tabular}{|c|c|c|c|c|c|c|c|}
\hline Ref. & $\begin{array}{c}\text { Age, } \\
\text { sex }\end{array}$ & $\begin{array}{c}\text { CKD stage (duration) and co- } \\
\text { morbidities }\end{array}$ & MTX endication & MTX dose & Clinical findings & 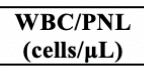 & Outcomes \\
\hline 18 & $52, \mathrm{~F}$ & Stage 5-HD & RA & $2.5 \mathrm{mg}, \mathrm{PO}$ & $\begin{array}{l}\text { Fever, pharyngitis, stomatitis-oral ulcerations, } \\
\text { rash, bacteremia, a large subdiaphragmatic } \\
\text { abscess at autopsy }\end{array}$ & $500 / 120$ & Died \\
\hline 40 & $57, \mathrm{M}$ & Stage 5-HD & RA & $5 \mathrm{mg}, \mathrm{PO}$ & $\begin{array}{l}\text { Fever, stomatitis with multiple ulcers, fatigue, } \\
\text { sepsis, jaundice }\end{array}$ & $100 /-$ & Improved \\
\hline 41 & $56, \mathrm{M}$ & $\begin{array}{l}\text { Stage } 5 \text {-HD ( } 7 \text { years), IgA } \\
\text { nephropathy, chronic hepatitis C } \\
\text { infection }\end{array}$ & Pustular psoriasis, PA & $2.5 \mathrm{mg}, \mathrm{PO}$ & $\begin{array}{l}\text { Fever, deranged liver function, paroxysmal } \\
\text { supraventricular tachycardia, acute coronary } \\
\text { syndrome }\end{array}$ & $500 /-$ & Died \\
\hline 42 & $68, \mathrm{M}$ & $\begin{array}{l}\text { Stage } 5-\mathrm{PD}, \mathrm{HT} \text {, nonischemic } \\
\text { cardiomyopathy, pulmonary HT, } \\
\text { wandering atrial pacemaker, } \\
\text { mesenteric atherosclerosis }\end{array}$ & $\begin{array}{l}\text { Refractory squamous } \\
\text { cell carcinoma of the } \\
\text { hands }\end{array}$ & $25 \mathrm{mg}, \mathrm{IL}$ & $\begin{array}{l}\text { Nausea, general malaise, shortness of breath, } \\
\text { pustular hand lesions, mucositis, deranged liver } \\
\text { function, fever }\end{array}$ & $1,300(600) /-$ & Improved \\
\hline * & $58, \mathrm{~F}$ & Stage 3 & RA & $12.5 \mathrm{mg}, \mathrm{PO}$ & $\begin{array}{l}\text { Abdominal pain, chest discomfort, vomiting, } \\
\text { skin rush }\end{array}$ & $1,200 / 160$ & Improved \\
\hline$*$ & $43, \mathrm{M}$ & Stage 5-HD (3 months) & Psoriasis, PA & $12.5 \mathrm{mg}, \mathrm{PO}$ & $\begin{array}{l}\text { Diarrhea, anorexia, chills, fever, sepsis, } \\
\text { mucositis, hepatotoxicity }\end{array}$ & $3,100 / 590$ & Died \\
\hline
\end{tabular}
arthritis, PO: orally, IM: intramuscular, IL: intralesional.

to 3 weeks after taking small doses of $2.5 \mathrm{mg} .{ }^{29}$ Therefore, it may not be appropriate to administer MTX therapy in patients with stage 4 and stage 5 CKD.

\section{Conclusion}

In our patients with renal dysfunction, MTXinduced pancytopenia developed within a few days after a single dose of MTX administration. Since the mechanisms of action and doseresponse relationships are not fully elucidated, there is considerable heterogeneity in RA therapy with low dose MTX. ${ }^{3}$ Recently, the 2016 update of European League Against Rheumatism recommendations for the management of $\mathrm{RA}$ suggests administering oral or subcutaneous MTX with short-term glucocorticoid initially, if tolerated, rapidly increasing the dose to 25$30 \mathrm{mg}$ per week and evaluating the response to treatment within 8-12 weeks. ${ }^{51}$ In patients with normal renal function, the recommended doses are within a range of 5 to $7.5 \mathrm{mg}$ per week. This dose can be increased by steps of 2.5 to $5 \mathrm{mg}$, up to a maximal dose of $15 \mathrm{mg} /$ week. However, in patients with renal dysfunction, if necessary, the initial weekly dose should be $2.5 \mathrm{mg}$, and the dose should be gradually increased by $2.5 \mathrm{mg}$ per week by close monitoring of whole blood count. The maximal dose should not exceed $5-7.5 \mathrm{mg}$. Some nephrologists recommend applying 30\% of the routine dosage. ${ }^{52}$ The American College of Rheumatology (ACR) recommend that a routine complete blood count should be performed every four weeks during the first three months of therapy, every 8 to 12 weeks from three to six months, and every 8 to 12 weeks thereafter, depending upon the nature and/or severity of abnormalities noted during monitoring. ${ }^{53}$ Folic acid $(1 \mathrm{mg} /$ day $)$ or folinic acid (2.5 mg/week) supplement may be beneficial in all patients receiving MTX, especially those with $\mathrm{MCV}>100 \mathrm{fl}$. These low doses does not interfere with the beneficial effects of MTX.35 If bone marrow toxicity is suspected, MTX treatment should be terminated immediately and the patient's clinical findings should be closely monitored. In fact, if the estimated creatinine clearance is below $30 \mathrm{~mL} / \mathrm{min}$, it would be more appropriate to prefer alternative treatments due to the risk of life-threatening myelosuppression.

\section{Conflict of Interest}

The authors declared that there are no potential conflicts of interest with respect to the research, authorship, and/or publication of this article.

\section{References}

1. O'Dell JR. Methotrexate use in rheumatoid arthritis. Rheum Dis Clin North Am. 1997 Nov;23(4):77996. doi: 10.1016/s0889-857x(05)70360-4.

2. Haustein UF, Rytter M. Methotrexate in psoriasis: 26 years' experience with low-dose long-term treatment. J Eur Acad Dermatol Venereol. 2000 Sep;14(5):382-8. doi: 10.1046/j.1468-3083.2000.00058.x.

3. Lucas CJ, Dimmitt SB, Martin JH. Optimising low-dose methotrexate for rheumatoid arthritis-A review. Br J Clin Pharmacol. 2019 Oct;85(10):2228-2234. doi: 10.1111/bcp.14057.

4. Hirshberg B, Muszkat M, Schlesinger O, Rubinow 
A. Safety of low dose methotrexate in elderly patients with rheumatoid arthritis. Postgrad Med J. 2000 Dec;76(902):787-9. doi: 10.1136/pmj.76.902.787.

5. Basile C, Montanaro A, Semeraro A. Should low-dose methotrexate therapy be prescribed to dialysis patients? Nephrol Dial Transplant. 2002 Mar;17(3):530-1. doi: 10.1093/ndt/17.3.530.

6. Kremer JM. Major side effects of low-dose methotrexate. In: O'Dell JR, Romain PL, eds. UpToDate (last update: Apr 06, 2020). Available at: https://www. uptodate.com/contents/major-side-effects-of-low-dosemethotrexate?search $=$ Major $\% 20$ side $\% 20$ effects $\% 20$ of $\% 2010 \mathrm{w}$-dose $\% 20$ methotrexate $\&$ source $=$ search resu 1 t \& s e 1 e c t e d T it 1 e $=1 \sim 150 \&$ u s a g e type=default\&display_rank=1. Accessed July 06, 2020.

7. Weinblatt ME, Fraser P. Elevated mean corpuscular volume as a predictor of hematologic toxicity due to methotrexate therapy. Arthritis Rheum. 1989 Dec;32(12):1592-6. doi: 10.1002/anr.1780321214.

8. Kivity S, Zafrir Y, Loebstein R, Pauzner R, Mouallem M, Mayan H. Clinical characteristics and risk factors for low dose methotrexate toxicity: a cohort of 28 patients. Autoimmun Rev. 2014 Nov;13(11):1109-13. doi: 10.1016/j.autrev.2014.08.027.

9. Kuitunen T, Malmström J, Palva E, Pettersson T. Pancytopenia induced by low-dose methotrexate. A study of the cases reported to the Finnish Adverse Drug Reaction Register From 1991 to 1999. Scand J Rheumatol. 2005 May-Jun;34(3):238-41. doi: 10.1080/03009740510018570.

10. Serraj K, Federici L, Maloisel F, Alt M, Andrès E. [Pancytopenia related to low-dose methotrexate: study of five cases and review of the literature]. Rev Med Interne. 2007 Sep;28(9):584-8. doi: 10.1016/j.revmed.2007.03.007.

11. Attar SM. Adverse effects of low dose methotrexate in rheumatoid arthritis patients. A hospitalbased study. Saudi Med J. 2010 Aug;31(8):909-15.

12. Gutierrez-Ureña S, Molina JF, García CO, Cuéllar ML, Espinoza LR. Pancytopenia secondary to methotrexate therapy in rheumatoid arthritis. Arthritis Rheum. 1996 Feb;39(2):272-6. doi: 10.1002/art.1780390214.

13. Ohosone Y, Okano Y, Kameda H, Hama N, Matsumura M, Nojima T, Nakamura K, Kuwana M, Ogasawara T, Hirakata M, Yoshida T, Mimori T, Akizuki M, Ikeda Y. Toxicity of low-dose methotrexate in rheumatoid arthritis--clinical characteristics in patients with MTX-induced pancytopenia and interstitial pneumonitis. Ryumachi. 1997 Feb;37(1):16-23.

14. Nakazaki S, Murayama T, Katoh S. Cytopenia associated with low dose pulse methotrexate in the treatment of rheumatoid arthritis. Ryumachi. 2001 Dec;41(6):929-37.

15. Sosin M, Handa S. Low dose methotrexate and bone marrow suppression. BMJ. 2003 Feb 1;326(7383):266-7. doi: 10.1136/bmj.326.7383.266.

16. Calvo-Romero JM. Severe pancytopenia associated with low-dose methotrexate therapy for rheumatoid arthritis. Ann Pharmacother. 2001 Dec;35(12):1575-7. doi: 10.1345/aph.1A052.

17. Preet Singh Y, Aggarwal A, Misra R, Agarwal V. Low-dose methotrexate-induced pancytopenia. Clin Rheumatol. 2007 Jan;26(1):84-7. doi: 10.1007/s10067-006-0301-7.

18. Ellman $\mathrm{MH}$, Ginsberg D. Low-dose methotrexate and severe neutropenia in patients undergoing renal dialysis. Arthritis Rheum. 1990 Jul;33(7):1060-1. doi: 10.1002/art.1780330724.
19. Grove ML, Hassell AB, Hay EM, Shadforth MF. Adverse reactions to disease-modifying antirheumatic drugs in clinical practice. QJM. 2001 Jun;94(6):309-19. doi: 10.1093/qjmed/94.6.309.

20. Songsiridej N, Furst DE. Methotrexate--the rapidly acting drug. Baillieres Clin Rheumatol. 1990 Dec;4(3):575-93. doi: 10.1016/s0950-3579(05)80008-1.

21. Ulrich CM, Yasui Y, Storb R, Schubert MM, Wagner JL, Bigler J, Ariail KS, Keener CL, Li S, Liu H, Farin FM, Potter JD. Pharmacogenetics of methotrexate: toxicity among marrow transplantation patients varies with the methylenetetrahydrofolate reductase C677T polymorphism. Blood. 2001 Jul 1;98(1):231-4. doi: 10.1182/blood.v98.1.231.

22. Berkun Y, Levartovsky D, Rubinow A, Orbach H, Aamar S, GrenaderT, Abou Atta I, Mevorach D, Friedman G, BenYehuda A. Methotrexate related adverse effects in patients with rheumatoid arthritis are associated with the A1298C polymorphism of the MTHFR gene. Ann Rheum Dis. 2004 Oct;63(10):1227-31. doi: 10.1136/ard.2003.016337.

23. Chess JA, Scholey G, Mikhail AI. Neutropenia associated with the use of low-dose methotrexate in a peritoneal dialysis patient. Nephrol Dial Transplant. 2004 Aug;19(8):2158-9. doi: 10.1093/ndt/gfh357.

24. Lim AY, Gaffney K, Scott DG. Methotrexate-induced pancytopenia: serious and under-reported? Our experience of 25 cases in 5 years. Rheumatology (Oxford). 2005 Aug;44(8):1051-5. doi: 10.1093/rheumatology/keh685.

25. Ajmani S, Preet Singh Y, Prasad S, Chowdhury A, Aggarwal A, Lawrence A, Misra R, Mishra R, Agarwal V. Methotrexate-induced pancytopenia: a case series of 46 patients. Int J Rheum Dis. 2017 Jul;20(7):846-851. doi: 10.1111/1756-185X.13004.

26. Kremer JM, Petrillo GF, Hamilton RA. Pharmacokinetics and renal function in patients with rheumatoid arthritis receiving a standard dose of oral weekly methotrexate: association with significant decreases in creatinine clearance and renal clearance of the drug after 6 months of therapy. J Rheumatol. 1995 Jan;22(1):38-40.

27. Chatham WW, Morgan SL, Alarcón GS. Renal failure: a risk factor for methotrexate toxicity. Arthritis Rheum. 2000 May;43(5):1185-6. doi: $10.1002 / 1529-0131(200005) 43: 5<1185:$ : A ID -

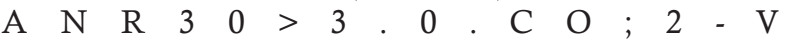

28. Sun CY, Lin HC, Chen YC, Tsai CR, Wu MS. Leukemoid Reaction After Methotrexate-Induced Pancytopenia in a Patient Undergoing Continuous Ambulatory Peritoneal Dialysis. Chang Gung Med J. Sep-Oct 2006;29(5):513-7.

29. Aristizabal-Alzate A, Nieto-Rios JF, Ocampo-Kohn C, Serna-Higuita LM, Bello-Marquez DC, ZuluagaValencia GA. Successful multiple-exchange peritoneal dialysis in a patient with severe hematological toxicity by methotrexate: case report and literature review. J Bras Nefrol. 2019 Jul-Sep;41(3):427-432. doi: $\quad$ 10.1590/2175-8239-JBN-2018-0095.

30. Boulanger $H$, Launay-Vacher V, Hierniaux P, Fau JB, Deray G. Severe methotrexate intoxication in a haemodialysis patient treated for rheumatoid arthritis. Nephrol Dial Transplant. 2001 May;16(5):1087. doi: 10.1093/ndt/16.5.1087.

31. Liu H, Liu F, Zhang M, Yan W, Sang H. Combined acute interstitial pneumonitis and pancytopenia induced by lowdose methotrexate in a hemodialysis patient treated for bullouspemphigoid.AnBrasDermatol.2015 May-Jun;90(3 
Suppl 1):43-5. doi: 10.1590/abd1806-4841.20153692.

32. Liu WC, ChenHC, ChenJS. Clinicaldilemmaoverlow-dose methotrexate therapy in dialysis patients: a case report and review of literature. Iran J Kidney Dis. 2014 Jan;8(1):81-4.

33. Diskin CJ, Stokes TJ, Dansby LM, Radcliff L, Carter TB. Removal of methotrexate by peritoneal dialysis and hemodialysis in a single patient with end-stage renal disease. Am J Med Sci. 2006 Sep;332(3):1568. doi.org/10.1097/00000441-200609000-00013.

34. Boey O, Van Hooland S, Woestenburg A, Van der Niepen P, Verbeelen D. Methotrexate should not be used for patients with end-stage kidney disease. Acta Clin Belg. 2006 Jul-Aug;61(4):166-9. doi: 10.1179/acb.2006.028.

35. Yang CP, Kuo MC, Guh JY, Chen HC. Pancytopenia after low dose methotrexate therapy in a hemodialysis patient: case report and review of literature. Ren Fail. 2006;28(1):95-7. doi: 10.1080/08860220500461328.

36. Mima A, Nagahara D, Tansho K. Methotrexate induced pneumatosis intestinalis under hemodialysis patient. Hemodial Int. 2017 Jan;21(1):E9-E12. doi: 10.1111/hdi.12459.

37. Seneschal J, Héliot-Hostein I, Taieb A. Pancytopenia induced by low-dose methotrexate in a haemodialysis patient treated for bullous pemphigoid. J Eur Acad Dermatol Venereol. 2007 Sep;21(8):11356 doi: 10.1111/j.1468-3083.2006.02122.x

38. Willner N, Storch S, Tadmor T, Schiff E. Almost a tragedy: severe methotrexate toxicity in a hemodialysis patient treated for ectopic pregnancy. Eur J Clin Pharmacol. 2014 Mar;70(3):261-3. doi: 10.1007/s00228-013-1608-3.

39. Bruyn GA, Velthuysen E, Joosten P, Houtman PM. Pancytopenia related eosinophilia in rheumatoid arthritis: a specific methotrexate phenomenon? J Rheumatol. 1995 Jul;22(7):1373-6.

40. Nakamura M, Sakemi T, Nagasawa K. Severe pancytopenia caused by a single administration of low dose methotrexate in a patient undergoing hemodialysis. J Rheumatol. 1999 Jun;26(6):1424-5.

41. Cheung KK, Chow KM, Szeto CC, Tai MH, Kwan BC, Li PK. Fatal pancytopenia in a hemodialysis patient after treatment with low-dose methotrexate. J Clin Rheumatol. 2009 Jun;15(4):17780. doi: 10.1097/RHU.0b013e3181a61f2d.

42. Flynn KN, Johnson MS, Brink WC, Smith DL. Pancytopenia, mucositis, and hepatotoxicity after intralesional methotrexate injection in a patient treated with peritoneal dialysis. Am J Health Syst Pharm. 2012 Apr 1;69(7):578-82. doi: 10.2146/ajhp110252.

43. Hoekstra M, van Ede AE, Haagsma CJ, van de Laar MA, Huizinga TW, Kruijsen MW, Laan RF. Factors associated with toxicity, final dose, and efficacy of methotrexate in patients with rheumatoid arthritis. Ann Rheum Dis. 2003 May;62(5):423-6. doi: 10.1136/ard.62.5.423.

44. Bressolle F, Bologna C, Kinowski JM, Sany J, Combe B. Effects of moderate renal insufficiency on pharmacokinetics of methotrexate in rheumatoid arthritis patients. Ann Rheum Dis. 1998 Feb;57(2):110-3. doi: 10.1136/ard.57.2.110.

45. Ahmad S, Shen FH, Bleyer WA. Methotrexateinduced renal failure and ineffectiveness of peritoneal dialysis. Arch Intern Med. 1978 Jul;138(7):1146-7.

46. SeyffartG.Poisonindex:Thetreatment ofacuteintoxication. Lengerich: Pabst Science Publishers; 1997;449-51.

47. Widemann BC, Balis FM, Kempf-Bielack B, Bielack S, Pratt CB, Ferrari S, Bacci G, Craft AW, Adamson PC. High-dose methotrexate-induced nephrotoxicity in patients with osteosarcoma. Cancer. 2004 May 15;100(10):2222-32. doi: 10.1002/cncr.20255.

48. Wall SM, Johansen MJ, Molony DA, DuBose TD Jr, Jaffe N, Madden T. Effective clearance of methotrexate using high-flux hemodialysis membranes. Am J Kidney Dis. 1996 Dec;28(6):846-54. doi: 10.1016/s0272-6386(96)90384-4.

49. Murashima M, Adamski J, Milone MC, Shaw L, Tsai DE, Bloom RD. Methotrexate clearance by high-flux hemodialysis and peritoneal dialysis: a case report. Am J Kidney Dis. 2009 May;53(5):871-4. doi: 10.1053/j.ajkd.2009.01.016.

50. Saland JM, Leavey PJ, Bash RO, Hansch E, Arbus GS, Quigley R. Effective removal of methotrexate by high-flux hemodialysis. Pediatr Nephrol. 2002 Oct;17(10):825-9. doi: 10.1007/s00467-002-0946-7.

51. Smolen JS, Landewé R, Bijlsma J, Burmester G, Chatzidionysiou K, Dougados M, Nam J, Ramiro S, Voshaar M, van Vollenhoven R, Aletaha D, Aringer M, Boers M, Buckley CD, Buttgereit F, Bykerk V, Cardiel M, Combe B, Cutolo M, van Eijk-Hustings Y, Emery P, Finckh A, Gabay C, Gomez-Reino J, Gossec L, Gottenberg JE, Hazes JMW, Huizinga T, Jani M, Karateev D, Kouloumas M, Kvien T, Li Z, Mariette X, McInnes I, Mysler E, Nash P, Pavelka K, Poór G, Richez C, van Riel P, Rubbert-Roth A, Saag K, da Silva J, Stamm T, Takeuchi T, Westhovens $\mathrm{R}$, de Wit $\mathrm{M}$, van der Heijde $\mathrm{D}$. EULAR recommendations for the management of rheumatoid arthritis with synthetic and biological disease-modifying antirheumatic drugs: 2016 update. Ann Rheum Dis. 2017 Jun;76(6):960977. doi: 10.1136/annrheumdis-2016-210715.

52. Kintzel PE, Dorr RT. Anticancer drug renal toxicity and elimination: dosing guidelines for altered renal function. Cancer Treat Rev. 1995 Jan;21(1):33-64. doi: 10.1016/0305-7372(95)90010-1.

53. Saag KG, Teng GG, Patkar NM, Anuntiyo J, Finney C, Curtis JR, Paulus HE, Mudano A, Pisu M, ElkinsMelton M, Outman R, Allison JJ, Suarez Almazor M, Bridges SL Jr, Chatham WW, Hochberg M, MacLean C, Mikuls T, Moreland LW, O'Dell J, Turkiewicz AM, Furst DE; American College of Rheumatology. American College of Rheumatology 2008 recommendations for the use of nonbiologic and biologic disease-modifying antirheumatic drugs in rheumatoid arthritis. Arthritis Rheum. 2008;59(6):762-784. doi:10.1002/art.23721. 